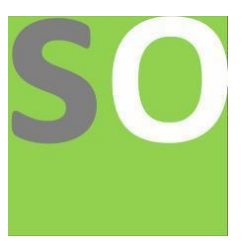

Article title: A Study on Tranche 2 Economic package of 20 Lakh Crore in India for COVID-19

Authors: Indhu N[1], Madhu S[2], Monisha D[3], Malarkodi K[4]

Affiliations: M.Kumarasamy College of Engineering[1]

Orcid ids: 0000-0001-6756-7704[1]

Contact e-mail: indhukishore1997@gmail.com

License information: This work has been published open access under Creative Commons Attribution License http://creativecommons.org/licenses/by/4.0/, which permits unrestricted use, distribution, and reproduction in any medium, provided the original work is properly cited. Conditions, terms of use and publishing policy can be found at https://www.scienceopen.com/.

Preprint statement: This article is a preprint and has not been peer-reviewed, under consideration and submitted to ScienceOpen Preprints for open peer review.

DOI: 10.14293/S2199-1006.1.SOR-.PPCKUSD.v1

Preprint first posted online: 26 June 2020

Keywords: Covid-19, Tranche 2, Lockdown 


\title{
A Study on Tranche 2 Economic package of 20 Lakh Crore in India for COVID-19
}

N. Indhu, II MBA, Department of Management, M.Kumarasamy College of Engineering, Karur, Tamilnadu, indhus.mba@mkce.ac.in

S.Madhu, II MBA, Department of Management, M.Kumarasamy College of Engineering, Karur, Tamilnadu,madhus.mba@mkce.ac.in

D.Monisha, II MBA, Department of Management, M.Kumarasamy College of Engineering, Karur, Tamilnadu, monishas.mba@mkce.ac.in

\begin{abstract}
Corona virus has affected the global economy in a worst condition where the Indian Government is only concerned with protecting the lives of people being laid on the economic resources and the condition of this country. This falsify situation that has been raised due to the migration of crores of people from various state and the loss of employment of many people is also the bad time in the history of mankind. The lockdown system has told people to be selfreliant by maintaining the distancing strategy with others. The lockdown made migrant workers tend to be vulnerable to the loss of employment and wages during an economic crisis in their host country, more so than native born workers. Lockdown in labour campus and dormitories can also increase the risk of contagion among migrant workers. Observing that government policy responses to the corona virus crisis have largely excluded migrants and their families back home, the World Bank said there is a strong case for including migrants in the near term health strategies of all countries, given the externalities associated with the health status of an entire population in the face of a highly contagious pandemic. The government has announced that about eight crore migrant workers, irrespective of whether they have ration cards, will get free food grains for the next two months.
\end{abstract}

Keywords: Covid-19, Tranche 2, Lockdown

\section{INTRODUCTION}

This article is related to the Covid-19 pandemic and explained about the free food for migrants over two months. The virus was first detected in Wuhan town, China on December 31st 
2019. On February 11, 2020, WHO (World Health Organization) officially named the corona virus as Covid-19. Tens of thousands of migrants have been fleeing cities on foot, trying to return to their villages. Many of these informal workers also form the backbone of city economies feared they would starve in the lockdown. The plight of these workers, many of whom have been walking for days without adequate food and water, has caused widespread anger in the country. Ms.Nirmala Sitharaman has announced that workers would be able to use ration cards usually only valid at village level. The ration card usually entitles holders to subsidised food. And also added that the move towards portable cards would benefit nearly 670 million people. In March, India said it would provide around 1.7 trillion rupees in direct cash transfer and food security measures mainly for the poor and migrant people.

Table 1.1 Announcement in tranche 2

\begin{tabular}{|c|l|c|}
\hline Sl. No & \multicolumn{1}{|c|}{ Measures } & Rs.Crores \\
\hline 1 & $\begin{array}{l}\text { Free Food Grains Supply to Migrants Workers for 2 } \\
\text { months }\end{array}$ & 3500 \\
\hline 2 & Interest Subvention for MUDRA Shishu Loans & 1500 \\
\hline 3 & Special Credit Facility to Street Vendors & 5000 \\
\hline 4 & Housing CLSS-MIG & 70000 \\
\hline 5 & $\begin{array}{l}\text { Additional Emergency Working Capital through } \\
\text { NABARD }\end{array}$ & 30000 \\
\hline 6 & Additional Credit through KCC & 200000 \\
\hline & \multicolumn{2}{c}{ Total } \\
\hline
\end{tabular}

\section{OBJECTIVE OF THE STUDY}

- To study the government announcement in tranche 2

- To know the advantages of the schemes 


\section{DISCUSSION:}

Discussion of tranche 2 by Union Finance \& Corporate Affairs Minister Smt. Nirmala Sitharaman under Aatmanirbhar Bharat Abhiyaan to support Indian economy in fight against COVID-19:

\subsection{Free Food Grains Supply to Migrants Workers for 2 months - 3500 Crores}

Free food grains supply to all migrants for the next two months. Migrants in various states require food - grains assistance. About 8 crore migrant workers will be provided with free food grains. The benefits are provided for those migrants who do not fall under the Food Security Act. The free food grains are provided to non - card holders, they are provided with $5 \mathrm{~kg}$ of wheat or rice per person and $1 \mathrm{~kg}$ chana per family per month for 2 months. Cost will be fully borne by the Government of India .State Government responsible for implementation, identification of migrants and full distribution and providing detailed guidelines to the people.

\subsection{Interest Subvention for MUDRA - Shishu Loans: MUDRA}

Micro Unit Development and Refinance Agency (MUDRA) was started to refinance loans of up to Rs 10 lakhs given by banks and other leading insititutions to small borrowers. Under the scheme, there are three categories - Shishu, Kishore and Tarun.

Small businesses under MUDRA have been disrupted the most \& has also impacted their capacity to pay EMIs. Loan moratorium has already been granted by RBI. The current portfolio of MUDRA - Shishu loan is Rs 1.62 Lakh crore maximum loan amount of Rs.50000. Government of India will provide Interest Subvention of 2\% for prompt payees for a period of 12 months. Relief of Rs.1500 crore to MUDRA - Shishuloanees.

\subsection{Credit Facility for Street Vendors}

This scheme is aimed at establishing the street vendors to resume their live hoods that have been adversely affected due to COVID - 19 lockdown. The scheme targets to benefits over 50 lakh street vendors, who had been vending on or before 24 march this year, in urban areas. The duration of the scheme is till March 2022. The street vendors belonging to the surrounding peri - urban or rural areas are being included as beneficiaries under the urban livelihoods programme for the first time. The vendors can avail a working capital loan up to ten thousand 
rupees, which is repayable in monthly installments in the tenure of one year. On timely and early repayment of t/he loan, an interest subsidy at the rate of the seven per cent per annum will be credited to the bank accounts of beneficiaries through Direct Benefit Transfer on six monthly basis.

\subsection{One Nation One Ration Card}

Under the National Food Security Act, 2013, about 81 crore persons are entitled to buy subsidized food grain — rice at Rs $3 / \mathrm{kg}$, wheat at Rs $2 / \mathrm{kg}$, and coarse grains at $\mathrm{Re} 1 / \mathrm{kg}$ - from their designated Fair Price Shops (FPS) of the Targeted Public Distribution System (TPDS). In the present system, a ration cardholder can buy food grains only from an FPS that has been assigned to her in the locality in which she lives. However, this will change once the 'One Nation, One Ration Card' system becomes operational nationally. Suppose a beneficiary lives in the district of Basti in Uttar Pradesh and migrates to Mumbai for work. Currently, she is no longer able to purchase subsidized food grains from a PDS shop in her new locality in Mumbai. However, under the 'One Nation, One Ration Card' system, the beneficiary will be able to buy subsidized food grains from any FPS across the country. The new system, based on a technological solution, will identify a beneficiary through biometric authentication on electronic Point of Sale devices installed at the FPSs, and enable that person to purchase the quantity of food grains to which she is entitled under the NFSA.

\subsection{Affordable Rental Housing Complexes (ARHC) for Migrant Workers / Urban Poor}

Government will launch a scheme under PMAY for migrant labour/urban poor to provide ease of living at affordable rent by, Under this development, government-funded housing in urban areas/cities will be converted into Affordable Rental Housing Complexes (ARHCs). This will be through the public-private partnership (PPP) model. Government housing complexes lying vacant will be converted so that it could be rented out to migrants on concessional rates. As migrant workers/urban poor have been facing challenges in getting houses at an affordable rent, this development was brought in. This will be for migrant workers, as well as urban poor to provide ease of living. Experts say the government-funded housing in cities being converted to Affordable Rental Housing Complexes through the public-private partnership will give a muchrequired impetus to the revival of the real estate sector and other related industries. Incentivizing manufacturing units, industries, institutions, associations to develop Affordable Rental Housing 
Complexes (ARHC) on their private land and operate. Incentivizing State Government Agencies or Central Government Organizations on the similar lines to develop Affordable Rental Housing Complexes (ARHC) and operate.

\subsection{Rs 6000 crore employment push using CAMPA funds}

Compensatory Afforestation Fund Management and Planning Authority (CAMPA) was set up under the compensatory Afforestation Fund Act, 2016. Plans worth Rs 6000 crores will be approved shortly. Funds to be used by State Governments for-

- Afforestation and plantation works, including in urban areas

- Artificial regeneration, assisted natural regeneration

- Forest management, soil \& moisture conservation works

- Forest protection, forest and wildlife related infrastructure development, wildlife protection and management etc

- Will create job opportunities in urban, semi-urban and rural areas.

- Will create job opportunities for Tribals /Adivasis

\subsection{Support for Migrants and Urban Poor during last 2 months}

Government of India has permitted State Governments to utilise State Disaster Response Fund (SDRF) for setting up shelter for migrants and providing them food and water etc. Central Government also released Rs 11002 crore of its contribution in advance to all States on 3rd April, to augment funds in their SDRF. Hygienically prepared three meals a day provided for the residents of Shelters for Urban Homeless (SUH) during the lockdown on March 28, 2020. 12,000 SHGs have produced 3 crore masks and 1.20 lakh litres of sanitizers. This gave additional employment opportunity to the urban poor. Disbursal of Revolving Fund (RF) to Self Help Groups was on-boarded on PAiSA Portal in April 2020 on a pilot basis in Gujarat and is now being rolled out across all the States in May 2020. 7,200 new Self Help Groups of urban poor have been formed during the period starting 15th March, 2020.

\subsection{MGNREGS support to returning Migrants}

In rural areas, the Mahatma Gandhi National Rural Employment Guarantee Act (MGNREGA) will be the main fulcrum to provide jobs to the migrant workers. In urban areas, depending on what skills the workers have, the administration will try to engage them in 
respective fields. But with revenues drying up for the states due to a complete halt in economic activities, providing livelihoods and wages to the huge number of returning migrants may not be economically sustainable for a long period of time. 14.62 Crore person-days of work generated till 13th May 2020. Actual Expenditure till date is around Rs. 10,000 Cr. Work offered to 2.33 Crore wage seekers yesterday in 1.87 Lac Gram Panchayats. 40-50\% more persons enrolled compared to May last year. Average wage rate rose to Rs. 202 from Rs. 182 in last FY. Drive being undertaken to enroll returning migrants. States/UTs advised to provide works to migrant workers as per the provisions of the Act. Planning for continuing MNREGA works in Monsoon as well: plantations, horticulture and livestock related sheds

\subsection{Direct Support to Farmers \& Rural Economy provided post COVID}

Under scheme 3 crore farmers with agricultural loans of Rs. 4.22 lakhs crore availed the benefit of 3 months loan moratorium. The Interest Subvention and Prompt Repayment Incentive on crop loans, due from 1st March, extended up to 31st May, 2020. The government is going to provide 25 lakh new Kisan Credit Cards sanctioned with a loan limit of Rs. 25,000 cr.

\subsection{Liquidity Support to Farmers \& Rural Economy provided post COVID}

Under this scheme 63 lakh loans of Rs. 86,600 crore approved in Agriculture between 1.3.2020 to 30.04.2020 for the benefit of farmers. Refinancing of Rs.29,500 crore provided by NABARD, to Cooperative Banks \& Regional Rural Banks in March, 2020 to help the poor people and for the growth of agriculture. Support of Rs. 4,200 crore provided under Rural Infrastructure Development Fund to States during March, 2020 for rural infrastructure. Working capital limit of Rs. 6,700 crore sanctioned for procurement of agriculture produce to State Government entities since March, 2020 to support the farmers and rural people.

\subsection{Labour Codes - Benefits for Workers}

Universalization of right of minimum wages and timely payment of wages to all workers including unorganized workers - presently minimum wages applicable to only $30 \%$ of workers. Statutory concept of National Floor Wage introduced: will reduce regional disparity in minimum wages. Fixation of minimum wages simplified, leading to less number of rates of minimum wages and better compliance. Appointment letter for all workers- this will promote formalization. Annual Health Check-up for employees. Occupational Safety \& Health (OSH) 
Code also applicable to establishments engaged in work of hazardous nature even with threshold of less than 10 workers.

Definition of inter-state migrant worker modified to include migrant workers employed directly by the employer, workers directly coming to destination State of their own besides the migrant workers employed through a contractor. Portability of welfare benefits for migrant workers. Extension of ESIC coverage pan-India to all districts and all establishments employing 10 or more employees as against those in notified districts/areas only. Extension of ESIC coverage to employees working in establishments with less than 10 employees on voluntary basis. Mandatory ESIC coverage through notification by the Central Government for employees in hazardous industries with less than 10 employees.

Social Security Scheme for Gig workers and Platform workers. Re-skilling fund introduced for retrenched employees. All occupations opened for women and permitted to work at night with safeguards. Provision for Social Security Fund for unorganized workers will be more beneficial for their employment. Gratuity for Fixed Tem Employment - Provision of gratuity on completion of one year service as against 5 years.

\subsection{Rs 70,000 crore boost to housing sector and middle income group through extension of CLSS}

The Credit Linked Subsidy Scheme (CLSS) is a benefit under the Pradhan MantriAwasYojana which focuses on helping the Middle Income Groups, Economically Weaker Sections, and Lower Income Groups in India by reduced EMIs.

Credit Linked Subsidy Scheme for Middle Income Group (Annual Income: Rs 6-18 lakhs) was operationalized from May 2017. CLSS was extended up to 31st March 2020.Scheme has benefitted 3.3 lakh middle class families so far. Government will extend the CLSS Scheme up to March 2021. 2.5 lakhs middle income families will benefit during 2020-21. Will lead to Investment of over Rs. 70,000 Crores in housing. Due to these facilities it will create job opportunities. This system will stimulate demand for steel, cement, transport and other construction materials. 


\subsection{Rs 30,000 crores Additional Emergency Working Capital Funding for farmers through NABARD}

The credit support measures announced for farmers isn't likely to enthuse the 14.5 crorestrong community, coming as it does in the wake of demands for full scale farm loan waivers. As part of the second tranche of AtmaNirbhar Bharat Abhiyan relief measures, Finance Minister Nirmala Sitharaman announced that additional credit support will be given to farmers through NABARD and the Kisan Credit Card facility.

Inadequate financial resources with Small and Marginal Farmers to help them. RRBs and Rural Cooperative banks are main source for credit. NABARD will extend additional refinance support of Rs. 30,000 crore for crop loan requirement of Rural Co-op Banks \& RRBs. This is over and above Rs 90,000 crore to be provided by NABARD through the normal refinance route during the year 2020. Front-loaded on-tap facility to 33 State Co-operative banks, 351 District Co-operative banks and 43 RRBs available on tap based on their lending. 3 crore farmers mostly small and marginal farmers are going to get benifited. To meet post-harvest (Rabi) \& current Kharifrequirement in May/June. Rs 2 lakh crore Concessional credit boost to 2.5 crore farmers through Kisan Credit Cards.

3.14 Rs 2 lakh crore Concessional credit boost to 2.5 crore farmers through Kisan Credit Cards

Pradhan MantriKisanSamman Nidhi (PM-KISAN) is a Central Sector scheme with 100\% funding from Government of India. The Scheme is effective from 1.12.2018.

Under this funding special drive to be undertaken to provide concessional credit to PMKISAN beneficiaries through Kisan Credit Cards.Fishermen and Animal Husbandry farmers will also be included in this drive. This will enable such farmers to gain access to institutional credit at concessional interest rate. 2.5 crore farmers will be covered and will benefit from credit flow of about Rs 2 lakh crores.

\section{CONCLUSION:}

This study found that Aatmanirbhar Bharat Abhiyaanscheme will support the poor people and also helps to grow the Indian economy. Food Minister Ram Vilas Paswan said that both the initiatives will help to solve the problems of migrant's workers. India has to improve its 
production and develop the market in global level by the use of big financial stimulus package which was given by Government of India. Tranche 2 package will stimulate the demand for steel, cement and transport industries. This will also help the farmers to cultivate more crops and leads to avoid demand in food products.

\section{REFERENCE:}

[1] https://www.newindianexpress.com/business/2020/may/14/covid-19-relief-packageagriculture-credit-support-fails-to-impress-farmers-unions-2143413.html

[2] https://www.paisabazaar.com/business-loan/nabard-scheme/

[3] https://krishijagran.com/agriculture-world/atmanirbhar-bharat-abhiyan-package-rs-30000-crore-additional-emergency-working-capital-for-farmers-through-nabard/

[4] https://www.thestatesman.com/india/atmanirbhar-bharat-package-sitharaman-announcesrelief-for-migrants-street-vendors-farmers-in-2nd-tranche-1502888638.html

[5] https://taxguru.in/finance/atma-nirbhar-bharat-part-2-poor-including-migrants-andfarmers.html

[6] https://currentaffairs.gktoday.in/rs-20000-lakh-crore-of-atma-nirbhar-bharat-abhiyansecond-tranche-announced-052020328737.html

[7] https://vjmglobal.com/information/atma-nirbhar-bharat/

[8] https://pib.gov.in/PressReleasePage.aspx?PRID=1624153

[9] https://vikaspedia.in/InDG/news/atmanirbhar-bharat

[10] https://www.cnbctv18.com/economy/nirmala-sitharaman-press-conference-live-fm-tospell-out-part-2-of-modis-20-lakh-crore-economic-package-shortly-5921981.htm/ 